\title{
Selective intraarterial radionuclide therapy with Yttrium-90 (Y-90) microspheres for unresectable primary and metastatic liver tumors
}

\author{
N Ozlem Kucuk ${ }^{1}$, Cigdem Soydal ${ }^{1 *}$, Seda Lacin ${ }^{1}$, Elgin Ozkan ${ }^{1}$ and Sadık Bilgic ${ }^{2}$
}

\section{Correction}

After the publication of this work [1], we became aware of the fact that there was date mistakes in the Abstract, Patients and method and Results sections. The correct text is included below.

In the 'Methods' section of the Abstract, the first sentence should have read:

"The clinical and follow-up data of 124 patients who were referred to our department for SIRT between June 2008 and October 2010 were evaluated retrospectively."

In The 'Patients' section of the Patients and Method, the first sentence should have read:

"The clinical and follow-up data of 124 patients who were referred to our department for SIRT between June 2008 and October 2010 were evaluated retrospectively."

In the 'Patients' section of the Results, the first sentence should have read:

"78 patients ( $49 \mathrm{M}$; $29 \mathrm{~F}$; mean age: $62.4+2.3$ years) received intra-arterial radionuclide treatments with $90 \mathrm{Y}$ for liver metastasis or primary HCC between June 2008 and October 2010."

\section{Author details}

'Ankara University, Medical School, Department of Nuclear Medicine, Ankara, Turkey. ${ }^{2}$ Ankara University, Medical School, Department of Radiology, Ankara, Turkey.

Received: 5 October 2011 Accepted: 6 October 2011

Published: 6 October 2011

\section{Reference}

1. Ozlem Kucuk N, SOYDAL Cigdem, Lacin Seda, et al: Selective intraarterial radionuclide therapy with Yttrium-90 (Y-90) microspheres for unresectable primary and metastatic liver tumors. World I Surg Oncol 2011, 9:86.

\footnotetext{
* Correspondence: csoydal@yahoo.com

'Ankara University, Medical School, Department of Nuclear Medicine, Ankara, Turkey
}

Full list of author information is available at the end of the article doi:10.1186/1477-7819-9-120

Cite this article as: Kucuk et al: Selective intraarterial radionuclide therapy with Yttrium-90 (Y-90) microspheres for unresectable primary and metastatic liver tumors. World Journal of Surgical Oncology 2011 9:120.
Submit your next manuscript to BioMed Central and take full advantage of:

- Convenient online submission

- Thorough peer review

- No space constraints or color figure charges

- Immediate publication on acceptance

- Inclusion in PubMed, CAS, Scopus and Google Scholar

- Research which is freely available for redistribution

\section{() Biomed Central}

